\title{
Analisis Kemampuan Siswa Kelas XI SMA Negeri 5 Palu dalam Menyelesaikan Soal-Soal Kategori Analisis pada Konsep Dinamika Partikel
}

\author{
Zahrah, Fihrin dan Yusuf Kendek \\ Zahrahrannu09@gmail.com \\ Program Studi Pendidikan Fisika FKIP Universitas Tadulako \\ Jl. Soekarno Hatta Km. 9 Kampus Bumi Tadulako Tondo Palu - Sulawesi Tengah
}

\begin{abstract}
Abstrak - Penelitian ini bertujuan untuk mendeskripsikan kemampuan siswa kelas XI SMA Negeri 5 Palu dalam menyelesaikan soal-soal kategori analisis pada konsep dinamika partikel. Jenis penelitian yang digunakan adalah deskriptif-kualitatif. Subjek penelitian ini yaitu siswa kelas XI IPA 5 SMA Negeri Palu yang berjumlah 24 orang. Data diperoleh melalui tes kemampuan analisis serta wawancara. Tes pkemampuan analisis terdiri atas 5 butir soal esai. Soal tersebut disusun berdasarkan taksonomi Anderson. Hasil penelitian menunjukkan bahwa nilai kemampuan analisis rata-rata yang diperoleh siswa sebesar 71,83 berada dalam kategori sangat sedang.
\end{abstract}

Kata Kunci: Analisis, Kemampuan Analisis, Dinamika Partikel

\section{PENDAHULUAN}

Pendidikan fisika sebagai bagian integral dari sistem pendidikan nasional, memegang peranan yang sangat penting bagi pengembangan ilmu pengetahuan dan teknologi. Hakikat tujuan pembelajaran fisika adalah untuk mengantarkan pemahaman siswa menguasai konsep-konsep dan keterkaitannya untuk dapat memecahkan masalah terkait dalam kehidupan sehari-hari.

Pelajaran Fisika cenderung dianggap sulit dan membosankan oleh sebagian siswa. Dalam pembelajaran di sekolah jarang diajarkan tentang contoh penerapan fisika dalam kehidupan sehari-hari. Sehingga siswa merasa Fisika merupakan pelajaran yang tidak bermanfaat setelah lulus nantinya.

Pada proses pembelajaran Fisika, siswa dibimbing menyelesaikan soal-soal. Tujuan siswa dibimbing menyelesaikan soal-soal Fisika adalah agar ketika dihadapkan pada soal-soal Fisika, siswa mampu menyelesaikannya dengan baik. Akan tetapi, masih terdapat siswa yang melakukan kesalahan dalam menyelesaikan soa-soal Fisika. Banyak faktor yang mungkin menyebabkan kesalahan yang dilakukan oleh siswa. Faktor-faktor tersebut dapat berasal dari dalam atau luar diri siswa. Faktor dari dalam diri siswa dapat berupa motivasi, minat, dan bakat siswa. Faktor dari luar diri siswa dapat berupa kondisi lingkungan, keluarga, guru, teman, dan bahan belajar.

Salah satu langkah dalam penilaian adalah menganalisis kemampuan siswa pada materi tertentu. Kemampuan analisis siswa dapat ditinjau dari kemampuan siswa dalam menyelesaikan soal-soal analisis atau soal dengan tipe C4. Analisis adalah kemampuan seseorang untuk merinci atau menguraikan suatu bahan atau keadaan menurut bagianbagian yang lebih kecil dan mampu memahami hubungan di antata bagian- bagian atau faktorfaktor yang satu dengan yang faktor yang lainnya [1].

Analisis kemampuan siswa dalam menyelesaikan soal kategori C4 telah dilaporkan oleh beberapa peneliti sebelumnya."kemampuan analisis yang dilatihkan pada siswa, menyebabkan siswa akan cenderung berpikir kritis".[2]. Kemampuan pemecahan masalah mahasiswa calon guru fisika pada materi dinamika masih rendah, faktor-faktor yang mempengaruhi adalah kebanyakan mahasiswa langsung memasukkan persaman tanpa menganalisis terlebih dahulu pokok permasalahan yang ditanyakan.[3]. kemampuan analisis siswa dalam menyelesaikan soal materi kalor tipe grafik masih kurang. Hal ini disebabkan karena siswa cenderung menhafal langkahnya [4].

Pada penelitian ini, peneliti mengkaji bagaimana tingkat kemampuan analisis yang dimiliki siswa kelas XI SMANegeri 5 Palu. Deskriptor analisis yang digunakan yaitu meliputi deskriptor memilah, membuat garis besar, menemukan koherensi, memadukan dan menkonstruksi [5]. Selanjutnya dalam penelitian ini peneliti hanya ingin mengetahui bagaimana kemampuan analisis yang dimiliki siswa kelas XI SMA Negeri 5 Palu serta materi yang akan diteliti dibatasi pada materi dinamika partikel. 


\section{METODE PENELITIAN}

Jenis penelitian ini merupakan penelitian deskriptif-kualitatif. Subjek penelitian yaitu siswa kelas XI SMA Negeri 5 Palu yang berjumlah 24 orang. Kemudian 6 orang dari subjek penelitian diambil sebagai responden yang dipilih berdasarkan kategori tinggi, sedang, dan rendah.

Instrumen yang digunakan yaitu tes kemampuan analisis materi dinamika partikel yang dibuat dalam bentuk soal-soal uraian sebanyak lima nomor.

\section{HASIL DAN PEMBAHASAN}

Secara keseluruhan hasil analisis tes kemampuan analisis untuk dinamika partikel, diperoleh skor rata-rata sebesar 71,83. Nilai tersebut berada pada kategori sedang.

Hasil kemampuan analsis untuk setiap ideskriptor yang digunakan disajikan pada Tabel 1 berikut.

TABEL 1 RANGKUMAN HASIL ANALISIS KEMAMPUAN ANALISIS SISWA

\begin{tabular}{|c|c|c|c|c|c|c|c|c|}
\hline \multirow[t]{2}{*}{ No } & \multirow[t]{2}{*}{ Deskriptor } & \multicolumn{5}{|c|}{$\begin{array}{l}\text { Jumlah Subjek yang } \\
\text { Menjawab per Deskriptor }\end{array}$} & & \multirow[t]{2}{*}{$\overline{\boldsymbol{x}}$} \\
\hline & & 5 & 4 & 3 & 2 & 1 & 0 & \\
\hline 1 & Memilah & 3 & 13 & 2 & 4 & 3 & 0 & \multirow{2}{*}{69,17} \\
\hline \multicolumn{2}{|c|}{ Persentase (\%) } & 13 & 54 & 8 & 17 & 13 & 0 & \\
\hline 2 & $\begin{array}{l}\text { Menmbuat } \\
\text { garis besar }\end{array}$ & 5 & 5 & 5 & 4 & 5 & 0 & \multirow[t]{2}{*}{65} \\
\hline \multicolumn{2}{|c|}{ Persentase (\%) } & 21 & 21 & 21 & 17 & 21 & 0 & \\
\hline 3 & $\begin{array}{l}\text { Menemukan } \\
\text { Koherensi }\end{array}$ & 5 & 9 & 6 & 4 & 0 & 0 & \multirow{2}{*}{72,50} \\
\hline \multicolumn{2}{|c|}{ Persentase (\%) } & 21 & 38 & 25 & 17 & 0 & 0 & \\
\hline 4 & Memadukan & 10 & 11 & 2 & 1 & 0 & 0 & \multirow{2}{*}{85} \\
\hline \multicolumn{2}{|c|}{ Persentase (\%) } & 42 & 46 & 8 & 4 & 0 & 0 & \\
\hline 5 & $\begin{array}{l}\text { Mendekonstru } \\
\text { ksi }\end{array}$ & 1 & 14 & 4 & 3 & 2 & 0 & \multirow[t]{2}{*}{67,50} \\
\hline $\mathrm{Pe}$ & entase (\%) & 4 & 58 & 17 & 13 & 8 & 0 & \\
\hline
\end{tabular}

Tabel 1 menunjukkan nilai yang diperoleh siswa untuk setiap deskriptor yang digunakan masih dalam kategori sedang. Deskriptor memadukan menjadi aspek dengan nilai tertinggi dari 5 deskriptor analisis yang digunakan. Nilai tersebut masih tergolong sedang.

Penelusuran kemampuan memahami soal dilakukan melalui wawancara berdasarkan kategori tinggi, sedang, dan rendah.

Setelah melakukan analisis terhadap hasil tes kemampuan berpikir kritis pada mahasiswa, diperoleh beberapa data sebagai berikut.

Hasil penelitian yang dilakukan diperoleh nilai rata-rata skor setiap deskriptor yaitu deskriptor memilah sebesar 69,17, deskriptor membuat garis besar sebesar 65, deskriptor menemukan koherensi sebesar 72,50, deskriptor memadukan sebesar 85, dan yang terakhir deskriptor mendekonstruksi sebesar 67,50. Dari hasil penelitian, R-18 memperoleh nilai tertinggi dengan nilai 92 dan yang terendah yaitu R-24 dengan nilai 40 .

Setelah itu dilakukan kategorisasi dan diketahui dari total 24 subyek penelitian 5 subyek berada pada kategori tinggi, 13 subjek berada pada kategori sedang, dan 6 subjek berada pada kategori rendah.

Selanjutnya total nilai yang diperoleh pada setiap soal diuraikan sebagai berikut.Untuk soal nomor 1, total nilai yang berhasil diperoleh adalah 83 , atau sebesar $69,17 \%$ dari total nilai maksimum yang bisa dicapai secara keseluruhan (120). Pada soal nomor satu, ada tiga subjek penelitian yang berhasil menjawab sampai dengan penilaian lima.

Untuk soal nomor 2, total nilai yang berhasil diperoleh adalah 78, atau sebesar $75 \%$ dari total nilai maksimum yang bisa dicapai secara keseluruhan (120). Pada nomor ini, ada 5 subjek penelitian yang memperoleh skor 5 . Namun, sebagian responden hanya fokus pada pada petambahan percepatan tanpa menjelaskan hubungan antara gaya dan percepatan sebagaimana penjelasan Hukum II Newton tentang hubungan gaya dan percepatan.

Untuk soal nomor 3, total nilai yang berhasil diperoleh adalah 87 , atau sebesar $72,5 \%$ dari total nilai maksimum yang bisa dicapai secara keseluruhan (120). Pada nomor ini, hanya ada lima subjek penelitian yang berhasil menjawab soal dengan benar dan memperoleh skor 5 . hal ini di sebabkan karena kurangnya penggunaan kata atau potongan kalimat untuk menjelaskan gambar secara keseluruhan. Sehingga siswa belum sempurna dalam menjelaskan gambar yang disajikan sesuai prinsip Hukum III Newton Untuk soal nomor 4, total nilai yang berhasil diperoleh adalah 102, atau sebesar $85 \%$ dari total nilai maksimum yang bisa dicapai secara keseluruhan (120). Pada nomor ini, ada 10 subjek penelitian yang mampu memberikan informasi sampai penilaian 5 . Pada soal ini diketahui pula bahwa sebagian besar subjek penelitian sudah mampu dalam memadukan antara rumus awal dengan pertanyaan selanjutnya.

Untuk soal nomor 5, total nilai yang berhasil diperoleh adalah 81 , atau sebesar $67,5 \%$ dari total skor maksimum yang bisa dicapai secara keseluruhan (120). Pada nomor ini, hanya ada satu subjek penelitian yang memperoleh skor 5 . Hal ini dikarenakan masih ada beberapa subjek penelitian yang kurang dalam mendekostruksi isi soal tentang perbedaan nilai gravitasi berdasarkan letak wilayah. 
Hasil analisis data berdasarkan tes kemampuan analisis yang dilakukan dan wawancara dengan siswa menunjukkan bahwa siswa masih tergolong sedang dalam menganalisis maksud dari pertanyaan yang ada pada soal. Hal ini disebabkan karena mereka belum terbiasa untuk melakukan analisis dari kasus yang disajikan. Siswa lebih sering diberikan soal-soal yang memuat nilai-nilai dan langsung dapat dikonversikan ke dalam rumus matematis.

Selain itu, pembelajaran yang menekankan aspek matematis dan kurangnya contoh kasus seperti soal-soal yang disajikan dalam tes kemampuan analisis ini diduga merupakan faktor dominan dalam mempengaruhi rendahnya skor siswa yang diperoleh dalam penelitian ini. Keadaan inilah yang secara tidak langsung membuat siswa kurang termotivasi untuk melakukan penggalian lebih dalam atau bahkan menganalisis setiap hal dalam konsep Dinamika Partikel.

\section{KESIMPULAN}

Analisis kemampuan siswa dalam menyelesaikan soal-soal kategori analisis untuk konsep Dinamika Partikel masih tergolong sedang. Hanya terdapat dua deskriptor, yaitu deskriptor memilah informasi dan mendekonstruksi berada dalam kategori cukup. Deskriptor menemukan koherensi, memfokuskan dan memadukan berada dalam kategori kurang. Bahkan deskriptor membuat garis besar berada dalam kategori kurang sekali.

Kurangnya kemampuan siswa dalam menyelesaikan soal-soal kategori analisis karena siswa lebih sering diberikan soal-soal yang memuat nilai-nilai dan langsung dapat ditransfer ke dalam rumus matematis.

\section{DAFTAR PUSTAKA}

[1] Arikunto, S. (2009). Dasar-Dasar Evaluasi Pendidkan. Jakarta: Bumi Aksara.

[2] Setyowibowo. (2009). Kemampuan Mahasiswa Menggunakan Pendekatan Analitis Kuantitatif Dalam Pemecahan Soal Fisika. Jurnal pendidikan matematika dan sains edisi 3.

[3] Tunnisa, T. (2016). Analisis Kemampuan Pemecahan Masalah Dinamika Partikel Pada Mahasiswa Calon Guru Fisika Berdasarkan Taksonomy Of Introductory Physics Problems (TIPP). Skripsi Sarjana pada Fakultas Keguruan dan Ilmu Pendidikan Universitas Tadulako.

[4] Wulandari, N. W. (2014). Kemampuan Analisis Siswa dalam Menyelesaikan Soal Materi Kalor Tipe Grafik. Prosiding Seminar Entrepreneurship. Universitas PGRI Semarang

[5] Anderson, Lorin W. dan David R. Krathwohl. (2010). Kerangka Landasan untuk Pembelajaran, Pengajaran, dan Asesmen (Revisi Taksonomi Pendidikan Bloom). Yogyakarta: Pustaka Pelajar 